quartz-fibre instrument might be devised, and perhaps it might contain its own recording apparatus in a compact form, so as to make registration a much easier and less cumbrous business than it has been hitherto.

When so much is unknown it is a mistake to begin by observing with too great intricacy of detail. The salient features should be first obtained, and then attention directed to the minutiæ; but one of the first things to do is to arrange that every swing in the curve shall mean a swing of atmospheric potential, and not a mere excursion of a heavy needle.

I hope that the energy, skill, and judgment of the various observers in the States, and of Mr. Mendenhall, the author of this valuable report, may be utilised through the resources of the U.S. Government by the inauguration of a fresh series of observations under somewhat different conditions, and without the hamper of any immediately specified practical object.

OLIVER J. LODGE.

\section{THE PRESERVATION OF THE NATIVE BIRDS OF NEW ZEALAND.}

$\mathrm{I}$ our issue of September I6 last year (vol. xlvi. p. 502) we printed an excellent memorandum drawn up by Lord Onslow, late Governor of New Zealand, relating to a proposal for the preservation of the native birds of that colony by setting apart two islands for this purpose, namely, I.ittle Barrier or Hauturn Island in the north, and Resolution Island in the south. As regards the first of these islands, we have lately received a copy of the report by Mr. Henry Wright (addressed to the Hon. John Ballance, Premier of New Zealand) upon the subject. According to Mr. Wright, Hauturn Island, in the Guif of Hauraki, which is almost circular in shape, and contains an area of from 9000 to 10,000 acres, rising in the middle to an elevation of about 2000 feet, is very well adapted for the purpose required. Writing with a thorough knowledge of all the north island, Mr. Wright is able to say that there is no other part of it where the native birds are to be found in anything like such profusion and variety. He gives a list of forty species to be met with within its limits, and mentions as particular varieties the stitch-bird or kotihe (Pogonornis cincta) and the large dark kiwi (Apteryx bulleri) as both found there. There are slight difficulties in the way of the project, such as the presence of about a dozen Maoris now living on the island, and of a claimant for the timber, which, in the shape of kauri pine (Dammara australis), is present in large quantities. There are no Weka Rails (Ocydromus) in the island to destroy the birds' eggs; and there are no bees, which, for some reasons, are considered to be highly inimical to the native birds in New Zealand. The wild pigs, formerly numerous, have been killed out; and the mutton-bird (CEstrelata gouldi), the young of which were formerly eaten by the pigs, will consequently be able to breed again undisturbed. Cats unfortunately are very numerous, but Mr. $\mathrm{W}$ right proposes to offer at once a reward for their destruction, which is, of course, of great importance.

Mr. Wright's report seems quite convincing as to the suitability of Hauturn Island for the object in view, but we regret to hear that some difficulties have arisen in the Parliament of New Zealand as to the appropriation of the funds required for the purpose.

Lord Onsiow, however, is not disposed to let the matter drop, and will, we are sure, be strongly supported by Lord Glasgow, the present Governor of New Zealand, in carrying the matter to a successful issue. The Council of the Zoological Society of London, whose attention has been called to the subject, have passed in its favour the following resolutions, which were communicated to a general meeting of that body on the I6th inst.

(I) The council of the Society have learnt with great NO. I 2 I 7 , VOL. 47 ] satisfaction the steps that were proposed to be taken by the Earl of Onslow, when Governor of New Zealand, and by the Houses of General Assembly for the preservation of the native birds of New Zealand, by reserving certain small islands suitable for the purpose, and by affording the birds special protection on these islands.

(2) The council much regret to hear that difficulties have been encountered in carrying out this plan as regards one of these islands (Little Barrier Island), and trust that the Government of New Zealand may be induced to take the necessary steps to overcome these difficulties and to carry out this excellent scheme in its entirety.

(3) The council venture to suggest that besides the native birds to be protected in these reserves shelter should also be afforded to the remarkable Saurian, the Tuatera Lizard (Sphenodon punctatus), which is at present restricted to some small islands on the north coast of New Zealand, in the Bay of Plenty.

These resolutions have been communicated to the present Governor of New Zealand, and will, we trust, be of some assistance to him in inducing his Ministers to carry this excellent scheme into execution.

\section{THE EARTHQUAKES IN ZANTE.}

THE following is a list of the shocks of earthquake at Zante, compiled from telegrams published in the Times and Standard:-January $3 \mathrm{r}$, at daybreak, the most destructive earthquake, of which, however, some warning must have been given, if we may judge from the comparatively small loss of life. Other slighter shocks followed during the day. February I, 2 a.m., another severe shock, felt also in Cephalonia. February 2 , two more violent shocks, one of which caused some fresh damage. February 3, further shocks, but less frequent and violent. February 5, another violent shock. February 6 , continued shocks of slight intensity, followed by three more severe ones in the afternoon and evening. February 7 , another violent shock in the morning, resulting in but little additional damage. February 8 , some slight shocks. February Io, some slight shocks in different districts. February II, I a.m., a somewhat severe shock, followed by a succession of shocks between 8 and 9 p.m. February I2, further shocks in the early morning, soon after midnight, and again at intervals during the day. February I 3 or I 4 , renewed slight shocks, accompanied by loud subterranean rumblings. The $A$ thens correspondent of the Times, telegraphing on February 20 , says : "The shocks of earthquake continue at Zante, with varying degrees of violence. No serious damage is reported, but those who are compelled to live in the half-ruined or insecure houses are exposed to frequent alarms." It is estimated that the total loss of property due to the shocks may exceed $£ 600,000$.

According to a telegram in the Times for February 6 , the tide in Venice on the evening of February I "ebbed so low as to leave several of the canals without water. The gondola traffic was interrupted at different points, and many of those craft were stranded. This phenomenon corresponded with the earthquakes at Zante and Cephalonia." A simple calculation will show, however, that this can hardly have been due to the principal shock. The straight line joining Zante and Venice passes almost directly up the Adriatic, and its length is roughly 720 miles. Taking the time between daybreak on January 31 and the evening of Feb. I at 36 hours, this would give for the sea-wave an average velocity of 20 miles an hour, corresponding to an average depth of about 30 feet, which is considerably less than the actual amount, the mean depth of the Adriatic being I Io fathoms.

Earthquakes are frequent in Zante, and sometimes very severe. One of the most destructive shocks, which occurred on October 30,1840 , is described by Ansted in 